\title{
Precipitation of solid phase calcium carbonates and their effect on application of seawater $S_{A}-T-P$ models
}

\author{
G. M. Marion ${ }^{1}$, F. J. Millero ${ }^{2}$, and R. Feistel ${ }^{3}$ \\ ${ }^{1}$ Desert Research Institute, 2215 Raggio Parkway, Reno, NV 89512, USA \\ ${ }^{2}$ University of Miami, 4600 Rickenbacker Causeway, Miami, FL 33149, USA \\ ${ }^{3}$ Leibniz Institute for Baltic Sea Research IOW, Seestr. 15, 18119, Warnemünde, Germany
}

Received: 14 October 2008 - Published in Ocean Sci. Discuss.: 28 January 2009

Revised: 11 June 2009 - Accepted: 13 July 2009 - Published: 21 July 2009

\begin{abstract}
At the present time, little is known about how broad salinity and temperature ranges are for seawater thermodynamic models that are functions of absolute salinity $\left(S_{A}\right)$, temperature $(T)$ and pressure $(P)$. Such models rely on fixed compositional ratios of the major components (e.g., $\mathrm{Na} / \mathrm{Cl}, \mathrm{Mg} / \mathrm{Cl}, \mathrm{Ca} / \mathrm{Cl}, \mathrm{SO}_{4} / \mathrm{Cl}$, etc.). As seawater evaporates or freezes, solid phases [e.g., $\mathrm{CaCO}_{3}(\mathrm{~s})$ or $\left.\mathrm{CaSO}_{4} 2 \mathrm{H}_{2} \mathrm{O}(\mathrm{s})\right]$ will eventually precipitate. This will change the compositional ratios, and these salinity models will no longer be applicable. A future complicating factor is the lowering of seawater $\mathrm{pH}$ as the atmospheric partial pressures of $\mathrm{CO}_{2}$ increase. A geochemical model (FREZCHEM) was used to quantify the $S_{A}-T$ boundaries at $P=0.1 \mathrm{MPa}$ and the range of these boundaries for future atmospheric $\mathrm{CO}_{2}$ increases. An omega supersaturation model for $\mathrm{CaCO}_{3}$ minerals based on pseudo-homogeneous nucleation was extended from $25-40^{\circ} \mathrm{C}$ to $3^{\circ} \mathrm{C}$. $\mathrm{CaCO}_{3}$ minerals were the boundary defining minerals (first to precipitate) between $3^{\circ} \mathrm{C}\left(\right.$ at $S_{A}=104 \mathrm{~g} \mathrm{~kg}^{-1}$ ) and $40^{\circ} \mathrm{C}\left(\right.$ at $S_{A}=66 \mathrm{~g} \mathrm{~kg}^{-1}$ ). At $2.82^{\circ} \mathrm{C}$, calcite $\left(\mathrm{CaCO}_{3}\right)$ transitioned to ikaite $\left(\mathrm{CaCO}_{3} 6 \mathrm{H}_{2} \mathrm{O}\right)$ as the dominant boundary defining mineral for colder temperatures, which culminated in a low temperature boundary of $-4.93^{\circ} \mathrm{C}$. Increasing atmospheric $\mathrm{CO}_{2}$ from $385 \mu \mathrm{atm}$ (390 MPa) (in Year 2008) to $550 \mu \mathrm{atm}(557 \mathrm{MPa}$ ) (in Year 2100) would increase the $S_{A}$ and t boundaries as much as $11 \mathrm{~g} \mathrm{~kg}^{-1}$ and $0.66^{\circ} \mathrm{C}$, respectively. The model-calculated calcite-ikaite transition temperature of $2.82^{\circ} \mathrm{C}$ is in excellent agreement with ikaite formation in natural environments that occurs at temperatures of $3^{\circ} \mathrm{C}$ or lower. Furthermore, these results provide a quantitative theoretical explanation
\end{abstract}

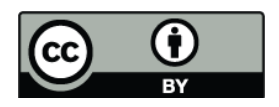

Correspondence to: G. M. Marion (giles.marion@dri.edu)
(FREZCHEM model calculation) for why ikaite is the solid phase $\mathrm{CaCO}_{3}$ mineral that precipitates during seawater freezing.

\section{Introduction}

At the present time, little is known about how broad salinity and temperature ranges are for seawater thermodynamic models that are functions of absolute salinity $\left(S_{A}\right)$ [or practical salinity $(S)$ ], temperature $(T)$ and pressure $(P)$, such as Feistel (2003, 2008) and Feistel and Marion (2007). Models that are used rely on fixed chemical composition ratios $\left(\mathrm{Na} / \mathrm{Cl}, \mathrm{Ca} / \mathrm{Mg}, \mathrm{Cl} / \mathrm{HCO}_{3}\right.$, etc., Millero et al., 2008). As seawater evaporates or freezes, eventually solid phases such as aragonite $\left(\mathrm{CaCO}_{3}\right)$, calcite $\left(\mathrm{CaCO}_{3}\right)$, or ikaite $\left(\mathrm{CaCO}_{3} 6 \mathrm{H}_{2} \mathrm{O}\right)$ will precipitate. When precipitation happens, the fixed ratios of various soluble species will change and the seawater salinity $\left(S_{A}\right)$ model will no longer be applicable.

Aragonite and calcite are generally the first solid phase salts that precipitate during seawater evaporation (Pytkowicz, 1973; McCaffrey et al., 1987; Maldonado et al., 1992; Morse et al., 1997; Zuddus and Mucci, 1998; Hardie, 2003; Millero, 2007; Morse et al., 2007). Aragonite and calcite have identical chemical compositions, but differ in their crystal structures and solubilities. How to handle these carbonates with chemical thermodynamic models is problematic because surface seawater is always supersaturated with these minerals. Fortunately, Morse and He (1993) have experimental data that calculates the degree of supersaturation $(\Omega)$ at the point where $\mathrm{CaCO}_{3}$ minerals will start to precipitate from seawater. Unfortunately, these datasets are only defined for 25 and $40^{\circ} \mathrm{C}$.

Published by Copernicus Publications on behalf of the European Geosciences Union. 
Table 1. Initial ion composition of the seawater sample $\left(S_{A}=35.147 \mathrm{~g} \mathrm{~kg}^{-1}\right)$.

\begin{tabular}{llll}
\hline Cation & Initial Molality & Anion & Initial Molality \\
\hline $\mathrm{Na}^{+}$ & 0.48606 & $\mathrm{Cl}^{-}$ & 0.56577 \\
$\mathrm{Mg}^{2+}$ & 0.05474 & $\mathrm{SO}_{4}^{2-}$ & 0.02926 \\
$\mathrm{Ca}^{2+}$ & 0.01066 & $\mathrm{Br}^{-}$ & 0.00087 \\
$\mathrm{~K}^{+}$ & 0.01058 & Alkalinity $^{\mathrm{a}}$ & $0.00228^{\mathrm{a}}$ \\
\hline
\end{tabular}

${ }^{\mathrm{a}}$ Alkalinity $=\mathrm{HCO}_{3}^{-}+2\left(\mathrm{CO}_{3}^{2-}+\mathrm{MgCO}_{3}^{0}+\mathrm{CaCO}_{3}^{0}\right)+\mathrm{OH}^{-}+$ $\mathrm{MgOH}^{-}$in equivalents $/ \mathrm{kg}\left(\mathrm{H}_{2} \mathrm{O}\right)$. Everything else in Table 1 are moles $/ \mathrm{kg}\left(\mathrm{H}_{2} \mathrm{O}\right)$.

A controversy that dates back a century deals with whether calcite or ikaite precipitates during seawater freezing (Ringer, 1906; Gitterman, 1937; Assur, 1958; Richardson, 1976; Weeks and Ackley, 1982; Marion, 2001; Dieckmann et al., 2008). Recently, for the first time, experimental measurements in Antarctic sea ice discovered ikaite crystals had formed during seawater freezing (Dieckmann et al., 2008). But how supersaturated calcite and saturated ikaite can be integrated into a theoretical model still remains an open question.

Another complicating factor for the long-term application of ranges for $S_{A}-T-P$ models is the global rise of atmospheric $\mathrm{CO}_{2}$ partial pressure from a pre-industrial (17501800) level of $280 \mu \mathrm{atm}$, to $385 \mu \mathrm{atm}$ in 2008, and potentially to $550 \mu \mathrm{atm}$ in 2100 (http://www.esrl.noaa.gov/gmd/ ccgg/trends/). Such $\mathrm{CO}_{2}$ trends will affect seawater $\mathrm{pH}$ and carbonate mineral solubilities that will alter $S_{A}-T-P$ applicability boundaries.

The specific objectives of this paper were to (1) establish salinity-temperature boundaries for $S_{A}-T-P$ models at $P=0.1 \mathrm{MPa}$ (Earth surface pressure), (2) establish the range of these boundaries for future atmospheric $\mathrm{CO}_{2}$ increases, and (3) reconcile, if possible, the controversy dealing with calcite-ikaite equilibrium during seawater freezing.

\section{Methods and materials}

The $S_{A^{-}} T$ boundaries for seawater $S_{A}-T-P$ models will be established with a theoretical chemical thermodynamic model called FREZCHEM (Marion and Kargel, 2008). The composition of seawater will be based on a newly established standard composition based on $S_{A}$ (Millero et al., 2008). And finally, $\mathrm{CaCO}_{3}$ supersaturation at precipitation will be integrated into FREZCHEM based on a pseudo-homogeneous nucleation model (Morse and He, 1993).

\subsection{FREZCHEM Model}

The FREZCHEM model is an equilibrium chemical thermodynamic model parameterized for concentrated electrolyte solutions using the Pitzer approach (Pitzer, 1991, 1995). The model has a temperature range of $<-70$ to $25^{\circ} \mathrm{C}$ and a pressure range of 0.1 to $100 \mathrm{MPa}$ ( 1 to 1000 bars) (Marion and Farren, 1999; Marion, 2001, 2002; Marion et al., 2003, 2005, 2006, 2008, 2009a, b; Marion and Kargel, 2008). The current version of the model is parameterized for the $\mathrm{Na}-\mathrm{K}-\mathrm{Mg}-\mathrm{Ca}-\mathrm{Fe}(\mathrm{II})-\mathrm{Fe}(\mathrm{III})-\mathrm{Al}-\mathrm{H}-\mathrm{Cl}-\mathrm{Br}-\mathrm{SO}_{4}-\mathrm{NO}_{3}-\mathrm{OH}-$ $\mathrm{HCO}_{3}-\mathrm{CO}_{3}-\mathrm{CO}_{2}-\mathrm{O}_{2}-\mathrm{CH}_{4}-\mathrm{Si}-\mathrm{H}_{2} \mathrm{O}$ system and includes 95 solid phases including ice, 15 chloride minerals, 35 sulfate minerals, 15 carbonate minerals, five solid-phase acids, three nitrate minerals, six acid salts, five iron oxide/hydroxides, four aluminum hydroxides, two silica minerals, two bromide sinks, and two gas hydrates. Inputs to the model are $1 \mathrm{~kg}$ $\mathrm{H}_{2} \mathrm{O}$, individual ion concentrations (Table 1), temperature, and pressure. Outputs include equilibrium compositions, $\mathrm{pH}$, density, water activity, and many other physicochemical properties (Marion and Kargel, 2008). Working copies of previously-published FREZCHEM models are available at the Internet site: http://frezchem.dri.edu.

This Pitzer-based model was used in Feistel and Marion (2007) to extend an $S_{A}-T-P$ model (Feistel, 2003) from $S_{A}=42 \mathrm{~g} \mathrm{~kg}^{-1}$ to $110 \mathrm{~g} \mathrm{~kg}^{-1}$ and the cold temperature boundary from -2 to $-7^{\circ} \mathrm{C}$. This model contains calcite, aragonite, vaterite, and ikaite chemistries. What FREZCHEM currently lacks in addressing the objectives of this paper is how to cope with $\mathrm{CaCO}_{3}$ supersaturation in seawater, which we will address below.

\subsection{Seawater properties}

The seawater molalities [moles $\mathrm{kg}\left(\mathrm{H}_{2} \mathrm{O}\right)^{-1}, \mathrm{~m}$ ] that will drive our simulations are taken from Millero et al. (2008) (Table 1). What is classified as alkalinity in Table 1 is "fixed" through charge balance with the other listed constituents. These tabular values will only change when $S_{A}$ changes. As $T$ and/or $P_{\mathrm{CO}_{2}}$ change, these tabular values can cause minor changes on $S_{A}$, unless solid phases start to precipitate. The minor effect on changing $S_{A}$ during $T$ and $P_{\mathrm{CO}_{2}}$ change is estimated to be about $0.04 \%$, based on soluble carbon contents, which can be safely ignored. Whether we represent the $S_{A}$ values as $35.147 \mathrm{~g} / \mathrm{kg}$ or as $35.133 \mathrm{~g} / \mathrm{kg}$ is minor. On the other hand, as $T$ and/or $P_{\mathrm{CO}_{2}}$ change, the individual alkalinity constituents (Table 1 footnote) can make major changes due to the effects of $P_{\mathrm{CO}_{2}}$ and $T$ on controlling $\mathrm{pH}$. For example at $S_{A}=35.147 \mathrm{~g} / \mathrm{kg}$ with $P_{\mathrm{CO}_{2}}=385 \mu \mathrm{atm}$, the $\mathrm{pH}$ at $40^{\circ} \mathrm{C}$ is equal to 8.318 with $\mathrm{CO}_{3}^{2-}=1.21 \mathrm{e}-4 \mathrm{~m}$, while $\mathrm{pH}$ at $0^{\circ} \mathrm{C}$ is equal to 8.056 with $\mathrm{CO}_{3}^{2-}=4.04 \mathrm{e}-5 \mathrm{~m}$. These major changes are factored into model calculations. In addition to these ions, we also included $\mathrm{B}(\mathrm{OH})_{3}=0.00033 \mathrm{~m}$. Several minor constituents $\left(\mathrm{Sr}^{2+}, \mathrm{B}(\mathrm{OH})_{4}^{-}, \mathrm{F}^{-}\right)$were excluded from our simulations. Overall, there was a small decrease in the standard $S_{A}$ from $35.165 \mathrm{~g} \mathrm{~kg}^{-1}$ (Practical Salinity $S=35.00)$ to the model-used $35.147 \mathrm{~g} \mathrm{~kg}^{-1}$. Our research efforts will focus exclusively on Absolute Salinity $\left(S_{A}\right)$. To convert $S_{A}$ to $S$ (Practical Salinity on the 1978 scale), 
one can use the relationship: $S=\left(35 /\left(35.16504 \mathrm{~g} \mathrm{~kg}^{-1}\right)\right)$ $S_{A}=0.995307 S_{A} /\left(\mathrm{g} \mathrm{kg}^{-1}\right)$ (Millero et al., 2008). Throughout the text, we will represent atmospheric $\mathrm{CO}_{2}$ in units of $\mu$ atm (=MPa/1.01325) as $P_{\mathrm{CO}_{2}}$. But the FREZCHEM model actually uses fugacity $\left(f_{\mathrm{CO}_{2}}\right)$ in model calculations.

\section{3 $\mathrm{CaCO}_{3}$ nucleation/supersaturation}

There are distinct differences among homogeneous, pseudohomogeneous, and heterogeneous nucleation and precipitation of $\mathrm{CaCO}_{3}$ minerals. Homogeneous precipitation of $\mathrm{CaCO}_{3}$ occurs in the absence of pre-existing precipitation surfaces (solid or soluble phases). Pseudo-homogeneous precipitation occurs on soluble colloidal particles, microbes, planktonic debris, and POC or reaction vessel surfaces (Morse and He, 1993). Heterogeneous precipitation occurs on pre-existing mineral solid phases. Heterogeneous precipitation is relevant where carbonate solid phases are in close contact with supersaturated waters (e.g., in shallow waters or in the presence of biotic carbonates). We will focus our attention in this paper primarily on pseudo-homogeneous $\mathrm{CaCO}_{3}$ precipitation using the Morse and He (1993) experimental data developed from natural seawater that likely contained surfaces (soluble and reaction vessel) for $\mathrm{CaCO}_{3}$ precipitation. We will also discuss two examples of heterogeneous precipitation that can be important in the interpretation of experiments with added crystals, and seawater environments with natural crystals.

In the seawater literature, it has long been known that seawater is supersaturated with carbonate minerals such as calcite and aragonite (Morse and Mackenzie, 1990; Millero and Sohn, 1992; Millero, 2007; Morse et al., 2007). Traditionally, the degree of supersaturation was described by the omega $(\Omega)$ concept:

$\Omega=\mathrm{IAP} / K$

where IAP is the calculated ion activity product [e.g., $\left.\left(a_{\mathrm{Ca}}\right)\left(a_{\mathrm{CO}_{3}}\right)\right]$ for a specific mineral (e.g., calcite), and $K$ is the solubility product for the mineral. For example, $\Omega$ for calcite at $S_{A}=35.147 \mathrm{~g} \mathrm{~kg}^{-1}$ and $t=25^{\circ} \mathrm{C}$ is calculated to be 5.6 with the FREZCHEM model (IAP=1.856e-8, $K=3.312 \mathrm{e}-9$ ). The seawater sample is 5.6-fold supersaturated with respect to calcite. While this is interesting, it provides no clue as to when such a seawater sample would actually start to precipitate a carbonate mineral during the evaporation or freezing process as $S_{A}$ increases.

John Morse and colleagues (Morse and He, 1993; Morse et al., 2007) have developed an empirical omega model that is geared to estimating the point where carbonate minerals will actually start to precipitate as a function of $S$ and $T$. In this case, the omega concept is defined as:

$\Omega($ calcite $)=\operatorname{IAP}\left(\mathrm{CaCO}_{3}\right) / K($ calcite $)$

In Eq. (2), the IAP is based on experimental measurements and theoretical calculations at the point where a " $\mathrm{CaCO}_{3}$ " mineral in natural seawater started to precipitate, likely either as calcite or aragonite with $\mathrm{Mg}$ substitutions. The $K$ (calcite) is a reference point based on the equilibrium of pure calcite. Despite the fact that Eq. (2) is defined in terms of calcite, the $\operatorname{IAP}\left(\mathrm{CaCO}_{3}\right)$ only predicts that an undefined $\mathrm{CaCO}_{3}$ mineral will precipitate. In what follows, we will use:

$\operatorname{IAP}\left(\mathrm{CaCO}_{3}\right)=\Omega$ (calcite $) \times K($ calcite $)=$

$\Omega$ (aragonite) $\times K$ (aragonite)

to calculate the $\operatorname{IAP}\left(\mathrm{CaCO}_{3}\right)$ at the point where a $\mathrm{CaCO}_{3}$ mineral will start to precipitate. We could also have used an aragonite reference state [ $K$ (aragonite)]. But in either case, the $\operatorname{IAP}\left(\mathrm{CaCO}_{3}\right)$ is identical (Eq. 3). Effectively, $\operatorname{IAP}\left(\mathrm{CaCO}_{3}\right)$ is the equilibrium constant for $\mathrm{CaCO}_{3}$ minerals in seawater. We will primarily run the FREZCHEM model at a fixed $\mathrm{T}$ under the evaporation option, where $S_{A}$ is steadily increasing because water is being removed, until our modelcalculated IAP agrees with the empirical IAP $\left(\mathrm{CaCO}_{3}\right.$ equilibrium constant) of Eq. (3) (or another mineral). At this point, the calculated salinity $\left(\mathrm{S}_{A}\right)$ represents the boundary for our $S_{A}-T-P$ model because a $\mathrm{CaCO}_{3}$ (or another) mineral has started to precipitate. We will also run the FREZCHEM model under the freezing option to establish the lower temperature boundary for the $S_{A}-T$ - $P$ model.

Bear in mind that while Eq. (3) specifically addresses $\mathrm{CaCO}_{3}$ mineral formation, this concept integrated into the FREZCHEM model does not preclude the possibility that other minerals (with other ions) could precipitate first during the evaporation or freezing process. Where solutions have become supersaturated with respect to specific minerals, the FREZCHEM model selects the solid phase that minimizes the $\mathrm{Ca}$ (or other ion) concentration as the most thermodynamically stable mineral. " $\mathrm{CaCO}_{3}$ " as defined in Eq. (3) is the only solid phase in the FREZCHEM model that is allowed to persist at the supersaturated level before precipitating. On the other hand, coping with the degree of supersaturation associated with Eq. (3) required that we remove several carbonate minerals from the FREZCHEM mineral database, including aragonite $\left(\mathrm{CaCO}_{3}\right)$, vaterite $\left(\mathrm{CaCO}_{3}\right)$, dolomite $\left[\mathrm{CaMg}\left(\mathrm{CO}_{3}\right)_{2}\right]$, magnesite $\left(\mathrm{MgCO}_{3}\right)$, and hydromagnesite $\left[3 \mathrm{MgCO}_{3} \mathrm{Mg}(\mathrm{OH})_{2} 3 \mathrm{H}_{2} \mathrm{O}\right]$. These minerals, except for aragonite that is a factor in Eq. (3), do not precipitate from seawater despite their supersaturation. So, removing them from the mineral database is perfectly valid for seawater simulations. Retention of the latter carbonate minerals in FREZCHEM would lead to their precipitation rather than the supersaturated " $\mathrm{CaCO}_{3}$ " as defined in Eq. (3). As pointed out above, " $\mathrm{CaCO}_{3}$ " likely represents either aragonite or calcite.

\section{Results}

In Fig. 1 are the experimental data that depict $\Omega$ (calcite) as a function of $S_{A}$ at 25 and $40^{\circ} \mathrm{C}$ under pseudo-homogeneous 


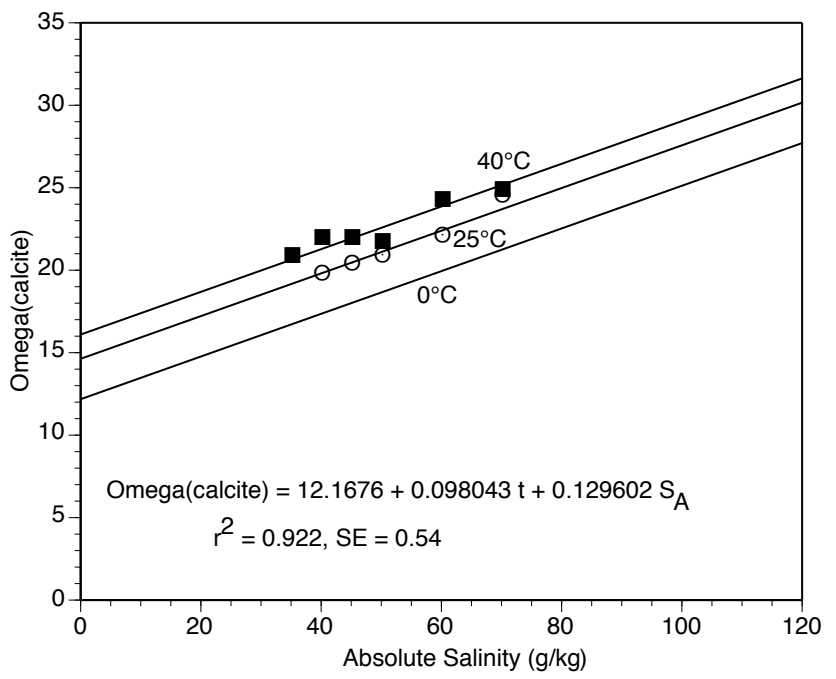

Fig. 1. The experimental data for supersaturation omega(calcite) (Morse and He, 1993; Morse et al., 2007) necessary for pseudohomogeneous nucleation of $\mathrm{CaCO}_{3}$ in seawater at $25^{\circ} \mathrm{C}$ (circles) and $40^{\circ} \mathrm{C}$ (squares), and an extrapolation to $0^{\circ} \mathrm{C}$.

nucleation (Morse and He, 1993; Morse et al., 2007). The $S$ values of the original data were converted to $S_{A}$ values (Fig. 1) by $S_{A}=1.004715\left(\mathrm{~g} \mathrm{~kg}^{-1}\right) S$. We fit a linear equation to these data, which is given by:

$\Omega($ calcite $)=-14.6128+0.098043 T+0.129602 S_{A}$

$(T$ in $K)$

where $r^{2}$ (coefficient of determination) $=0.922$, and SE (standard error) $=0.54$ (Steel et al., 1997). The three coefficients in Eq. (4) (and Fig. 1) are all statistically significant at the $<1 \%$ chance of a Type I error (Steel et al., 1997). Extrapolation of the equation to $0^{\circ} \mathrm{C}$ is also depicted in Fig. 1. The equation fits to data at 25 and $40^{\circ} \mathrm{C}$ seem reasonably good. The extrapolation to lower temperatures will be examined below (see Sect. 4 on Discussion).

Now given an equation that allows one to calculate $\Omega$ (calcite) as a function of $S_{A}$ and $T$ (Eq. 4), we can estimate the IAP $\left(\mathrm{CaCO}_{3}\right)$ of Eq. (3). Next, we ran the FREZCHEM model under the evaporation process, at a fixed $T$ and a starting $S_{A}=35.147 \mathrm{~g} \mathrm{~kg}^{-1}$, until the model-calculated IAP equilibrated with $\mathrm{IAP}\left(\mathrm{CaCO}_{3}\right)$ of Eq. (3) to form carbonates, or other minerals. This process allowed us to place $S_{A}$ and $T$ limits where solid phase minerals start to form. The results of these calculations for Year 2008 with $\mathrm{CO}_{2}=385 \mu \mathrm{atm}$ are given in Fig. 2 (solid lines). As an example, for a temperature of $20^{\circ} \mathrm{C}$ with initial $S_{A}=35.147 \mathrm{~g} \mathrm{~kg}^{-1}$, we evaporated the solution with FREZCHEM until $\mathrm{CaCO}_{3}$ started to precipitate at $S_{A}=83.1 \mathrm{~g} \mathrm{~kg}^{-1}$, which sets the boundary limit for an $S_{A}-T-P$ model at $T=20^{\circ} \mathrm{C}$ and $S_{A}=83.1 \mathrm{~g} \mathrm{~kg}^{-1}$. Similar calculations established the boundary between 3 and $40^{\circ} \mathrm{C}$

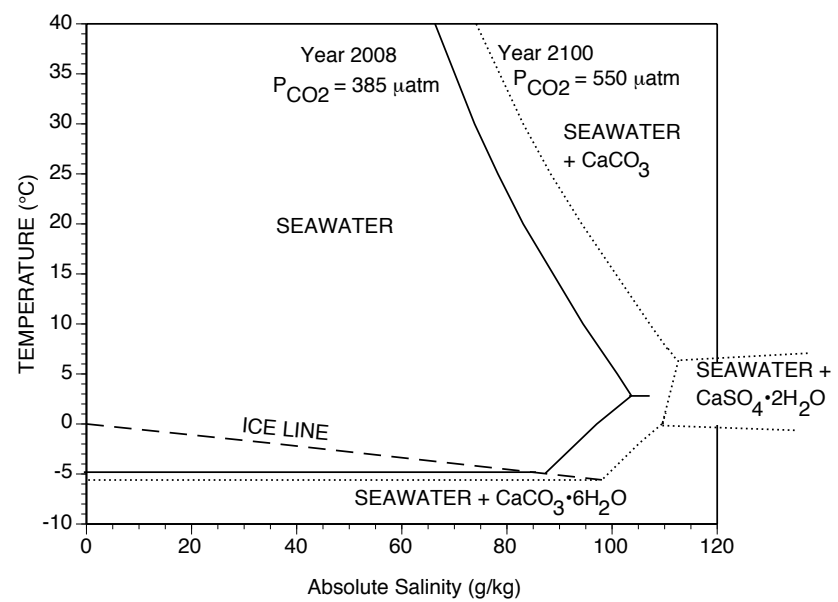

Fig. 2. The pseudo-homogeneous nucleation boundaries for $S_{A}-T$ $P$ models in Year 2008 (solid lines) and potentially in Year 2100 (dashed lines).

(Fig. 2). Aragonite is likely the dominant $\mathrm{CaCO}_{3}$ mineral between 8 and $40^{\circ} \mathrm{C}$, and calcite is likely the dominant $\mathrm{CaCO}_{3}$ mineral between 3 and $8^{\circ} \mathrm{C}$ (Morse et al., 2007). Note that in this temperature range of $3-40^{\circ} \mathrm{C}$, the boundary increases with decreasing temperature because the solubility of $\mathrm{CaCO}_{3}$ minerals increases with decreasing temperature.

At a temperature of $2.82^{\circ} \mathrm{C}$, the FREZCHEM model predicts that ikaite should start precipitating instead of $\mathrm{CaCO}_{3}$. Because ikaite solubility decreases with decreasing temperature, the slope of the curve changes from that for $\mathrm{CaCO}_{3}$ solubility (Fig. 2).

Now to establish the lower temperature limit, we needed to extend the calculations to the point where minerals start precipitating at cold temperatures. If we start at $25^{\circ} \mathrm{C}$ with $S_{A}=35.147 \mathrm{~g} \mathrm{~kg}^{-1}$, then lowering temperature will eventually reach the "ice line" in Fig. 2 at $t=-1.9^{\circ} \mathrm{C}$. Ice formation, per se, does not limit the range of $S_{A}-T-P$ models because relatively pure ice forms concentrating all solution phase constituents equally, therefore leaving ratios such as $\mathrm{Ca} / \mathrm{Mg}$ unchanged. But as temperature continues to changes below $-1.9^{\circ} \mathrm{C}$, the freezing process will follow the ice line changing rapidly in $S_{A}$ until it hits the ikaite line at $-4.93^{\circ} \mathrm{C}$ with $S_{A}=87.3 \mathrm{~g} \mathrm{~kg}^{-1}$ (Fig. 2). The lower $t$ limit for all phases that lead to ice formation is $-4.93^{\circ} \mathrm{C}$.

The atmospheric $\mathrm{CO}_{2}$ has changed historically from $280 \mu \mathrm{atm}$ in pre-industrial years, to $385 \mu \mathrm{atm}$ in 2008 , and potentially to $550 \mu \mathrm{atm}$ by 2100 (http://www.esrl.noaa.gov/ $\mathrm{gmd} / \mathrm{ccgg} /$ trends/). The corresponding increases in $P_{\mathrm{CO}_{2}}$ in surface ocean water results in a decrease in seawater $\mathrm{pH}$ (at $S_{A}=35 \mathrm{~g} \mathrm{~kg}^{-1}, t=25^{\circ} \mathrm{C}$ ) from 8.38 in pre-industrial years, to 8.27 in 2008 , and to 8.14 in 2100 (Fig. 3). These $\mathrm{pH}$ values were estimated with the FREZCHEM model that defines $\mathrm{pH}=-\log _{10}\left(\mathrm{H}^{+}\right)$, where the parentheses define $\mathrm{H}^{+}$activity. In contrast, had we estimated $\mathrm{pH}$ 


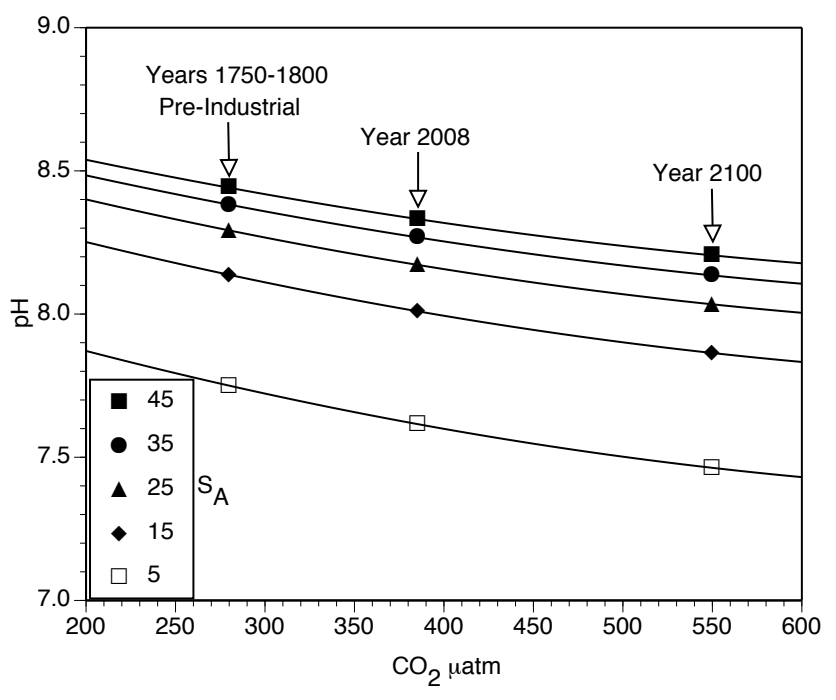

Fig. 3. Model calculated seawater $\mathrm{pH}$ values as a function of $\mathrm{CO}_{2} \mu \mathrm{atm}$ for $S_{A}$ values of $5-45 \mathrm{~g} \mathrm{~kg}^{-1}$ at $25^{\circ} \mathrm{C}$.

using the seawater scale (SWS) (Millero, 2001) that defines $\mathrm{pH}(\mathrm{SWS})=-\log _{10}\left[\mathrm{H}^{+}+\mathrm{HSO}_{4}^{-}+\mathrm{HF}\right]$, where the brackets define concentrations, then the corresponding $\mathrm{pH}$ values are $8.13,8.02$, and 7.88 , respectively, about $0.25 \mathrm{pH}$ units lower than the $\mathrm{pH}$ values in Fig. 3. Either scale can be used to define $\mathrm{pH}$ in seawater. But, caution must be used to assure consistency in how the $\mathrm{pH}$ options are defined and subsequent applications to $\mathrm{H}^{+}$equilibria. See Millero (2001) for more details on $\mathrm{pH}$ scale variability.

Changing $S_{A}$, especially lower values, will have a major influence on the relationship of $\mathrm{CO}_{2}$ and $\mathrm{pH}$ (Fig. 3). The Baltic Sea is a classic case where seawater $S_{A}$ is highly variable, from below $1 \mathrm{~g} \mathrm{~kg}^{-1}$ in the coastal lagoons, over 8$12 \mathrm{~g} \mathrm{~kg}^{-1}$ in the central Gotland Sea, to about $25 \mathrm{~g} \mathrm{~kg}^{-1}$ at the Danish Straits, with significant temporal variability from the daily to the decadal (climatological) time scales (see e.g. online figures of Feistel et al., 2008). In addition, brackish Baltic seawater contains anomalously high $\mathrm{CaCO}_{3}$ concentrations (Rohde, 1966; Millero and Kremling, 1976; Feistel and Weinreben, 2008).

A decreasing $\mathrm{pH}$ due to increasing atmospheric $\mathrm{CO}_{2}$ will cause $\mathrm{CaCO}_{3}$ minerals to increase in solubility, which will increase the salinity-temperature boundaries by up to $11 \mathrm{~g} \mathrm{~kg}^{-1}$ and $0.66^{\circ} \mathrm{C}$ by 2100 (dashed lines, Fig. 2). Also, interestingly, the model predicts that gypsum $\left(\mathrm{CaSO}_{4} 2 \mathrm{H}_{2} \mathrm{O}\right)$ should be the boundary precipitating mineral between 0 and $6^{\circ} \mathrm{C}$ in 2100 (Fig. 2). We also made an approximation of where gypsum should start to first precipitate between 2008 and 2100 , which is at $S_{A}=109.5 \mathrm{~g} \mathrm{~kg}^{-1}, t=2.95^{\circ} \mathrm{C}$, and $\mathrm{CO}_{2}=450 \mu \mathrm{atm}$.

\section{Discussion}

Our efforts have resulted in placing $S_{A}-T$ boundaries for using $S_{A}-T-P$ models at $P=0.1 \mathrm{MPa}$, which was the primary purpose of this paper. But Figs. 1 and 2 deal with pseudohomogeneous nucleation of solid phase $\mathrm{CaCO}_{3}$. McCaffrey et al. (1987) estimated that $\mathrm{CaCO}_{3}$ starts precipitating from seawater at 1.8 -fold brine concentration at a temperature of $\approx 31^{\circ} \mathrm{C}$. Those experiments were made at the Morton Bahamas solar salt production facility on Great Inagua Island in the Bahamas and represent heterogeneous nucleation because of the shallow depths that likely contain $\mathrm{CaCO}_{3}$ solid phases (likely aragonite) nucleation sites. Multiplying $1.8 \times 35$ leads to a salinity of $63 \mathrm{~g} \mathrm{~kg}^{-1}$ at the point where $\mathrm{CaCO}_{3}$ starts to precipitate. This result compares to a salinity of $73 \mathrm{~g} \mathrm{~kg}^{-1}$ at $31^{\circ} \mathrm{C}$ under pseudo-homogeneous nucleation (Fig. 2). Gitterman (1937) examined $\mathrm{CaCO}_{3}$ formation resulting from seawater freezing where his experimental aqueous solutions $\left(S_{A}=33.34 \mathrm{~g} \mathrm{~kg}^{-1}\right)$ were likely seeded with calcite crystals (Marion, 2001). His first experimental point, after freezing started at $-1.8^{\circ} \mathrm{C}$, was at $-3.5^{\circ} \mathrm{C}$ where $\mathrm{CaCO}_{3}$ was clearly precipitating. Because he seeded the aqueous phase with $\mathrm{CaCO}_{3}$ crystals, this represents heterogeneous nucleation. The brine concentration factor between -1.8 and $-3.5^{\circ} \mathrm{C}$ is 2.0 -fold, which represents a maximum concentration factor because $\mathrm{CaCO}_{3}$ could have started precipitating at any temperature between -1.8 and $-3.5^{\circ} \mathrm{C}$. The point is that heterogeneous nucleation at a temperature that could be as low as $-3.5^{\circ} \mathrm{C}$ still led to a lower brine concentration than was the case for ikaite that precipitated at a temperature of $-4.9^{\circ} \mathrm{C}$ under pseudo-homogeneous precipitation (Fig. 2). Heterogeneous nucleation in the presence of $\mathrm{CaCO}_{3}$ minerals will reduce the applicability range of $S_{A}-T$ $P$ models. Unfortunately, the data to place a broad range on heterogeneous nucleation is relatively limited. Fortunately, pseudo-homogeneous nucleation (Fig. 2) is more realistic for the bulk of Earth seawater. The experimental data for Figure 1 were based on natural seawater that probably contained soluble nucleation sites associated with clay particles, microbes, planktonic debris, and POC, which is why Morse and $\mathrm{He}$ (1993) defined the process as pseudo-homogeneous nucleation of $\mathrm{CaCO}_{3}$. This is an appropriate nucleation process for natural seawater, which we modeled in Fig. 2.

What is perhaps most intriguing about the theoretical model calculations is that the model predicts a transition from $\mathrm{CaCO}_{3}$ (probably calcite) to ikaite at a temperature of $2.82^{\circ} \mathrm{C}$ and a salinity of $104 \mathrm{~g} / \mathrm{kg}$ (Fig. 2). Natural occurrences of ikaite appear to have water temperatures of $3^{\circ} \mathrm{C}$ or lower (Pauley, 1963; Bischoff et al., 1993; Larsen, 1994; Omelon et al., 2001), which is in excellent agreement with our model calculation. In the Dieckmann et al. (2008) paper that recently identified ikaite formation in sea ice, great care was taken to keep the temperature of the isolated ikaite crystals between 0 and $2{ }^{\circ} \mathrm{C}$ during sample analyses because ikaite easily decomposes at higher temperatures 
forming calcite crystals (Omelon et al., 2001; Dieckmann et al., 2008). At the transition temperature of $2.82^{\circ} \mathrm{C}$, the $\Omega$ (calcite) value is 25.9 , meaning that calcite is 25.9 -fold supersaturated. The fact that this high $\Omega$ (calcite) value accurately predicts the transition from supersaturated calcite to saturated ikaite at $3^{\circ} \mathrm{C}$ is strong support for the broad-range equation for $\Omega$ (calcite) (Eq. 4, Fig. 1) in which we extended the temperature from $25-40^{\circ} \mathrm{C}$ to $3^{\circ} \mathrm{C}$ and salinity from 35 $70 \mathrm{~g} / \mathrm{kg}$ (Fig. 1) to $104 \mathrm{~g} / \mathrm{kg}$ (Fig. 2). Furthermore, this result argues in favor of ikaite formation during the freezing process, which, as we mentioned earlier, has been controversial for over a century (Ringer, 1906; Gitterman, 1937; Assur, 1958; Richardson, 1976; Weeks and Ackley, 1982; Marion, 2001; Dieckmann et al., 2008). The fact that the theoretical FREZCHEM model can quantitatively predict $\mathrm{CaCO}_{3}$ mineral formation in seawater across a broad range of $S_{A}-T$ values is a major step forward in geochemical modeling.

A limitation, at present, is that the equation for estimating $\Omega$ (calcite) is based on seawater $S_{A}$ that works well for seawater compositions, but may not work for other salt assemblages. For example, calcite precipitation in seawater requires high $\Omega$ values (high supersaturation) (Figs. 1-2), which is due to seawater inhibitory components such as $\mathrm{Mg}^{2+}$, orthophosphate, and organic matter (Pytkowicz, 1973; Bischoff et al., 1993; Morse et al., 2007). Other saline waters with different compositions (e.g., exceedingly low or high $\mathrm{Mg}^{2+}$, orthophosphate, and organic matter) would likely respond quite differently with respect to calcite precipitation. Another limitation is how to deal with pressure effects. The $S_{A}-T$ data used to estimate the omega values (Fig. 1) were based on a single set of experiments that were done at $P=0.1 \mathrm{MPa}$ (Morse and He, 1993). Nevertheless, as formulated in this paper, we can accurately simulate surface properties of seawater, which by itself is a major improvement in understanding seawater chemistry.

Edited by: W. Jenkins

\section{References}

Assur, A.: Composition of sea ice and its tensile strength, in: Arctic Sea Ice, Publication 598, National Acad. Sci.-Nat. Res. Council, Washington, DC, 106-138, 1958.

Bischoff, J. L., Fitzpatrick, J. A., and Rosenbauer, R. J.: The solubility and stabilization of ikaite $\left(\mathrm{CaCO}_{3} 6 \mathrm{H}_{2} \mathrm{O}\right)$ from $0^{\circ}$ to $25^{\circ} \mathrm{C}$ : Environmental and paleoclimatic implications for thinolite tufa, J. Geol., 101, 21-33, 1993.

Dieckmann, G. S., Nehrke, G., Papadimitriou, S., Göttlicher, J., Steininger, R., Kennedy, H., Wolf-Gladrow, D., and Thomas, D. N.: Calcium carbonate as ikaite crystals in Antarctic sea ice, Geophys. Res. Lett., 35, L08501, doi:10.1029/2008GL033540, 2008.

Feistel, R.: A new extended Gibbs thermodynamic potential of seawater, Progr. Ocean., 58, 43-114, 2003.

Feistel, R.: A Gibbs function for seawater thermodynamics for $-6^{\circ} \mathrm{C}$ to $80^{\circ} \mathrm{C}$ and salinity up to $120 \mathrm{~g} / \mathrm{kg}$, Deep-Sea Res. I, 55, 1639-1671, 2008.
Feistel, R. and Marion, G. M.: A Gibbs-Pitzer function for highsalinity seawater thermodynamics, Progr. Ocean., 74, 515-539, 2007.

Feistel, R. and Weinreben, S.: Is Practical Salinity conservative in the Baltic Sea? Oceanologia, 50, 73-82, 2008.

Feistel, R., Nausch, G., and Wasmund, N.: State and Evolution of the Baltic Sea, 1952-2005. A Detailed 50-Year Survey of Meteorology and Climate, Physics, Chemistry, Biology, and Marine Environment, John Wiley \& Sons, Inc., Hoboken, NJ, 2008.

Gitterman, K. E.: Thermal analysis of sea water, CRREL TL 287, USACRREL, Hanover, New Hampshire, 1937.

Hardie, L. A.: Secular variations in Precambrian seawater chemistry and the timing of Precambrian aragonite seas and calcite seas, Geology, 31, 785-788, 2003.

Larsen, D.: Origin and paleoenvironmental significance of calcite pseudomorphs after ikaite in the Oligocene Creede Formation, Colorado, J. Sed. Res., A64, 593-603, 1994.

Maldonado, C. F. E., Giroir, G., Dandurand, J. L., and Schott, J.: The dissolution of calcite in seawater from $40^{\circ}$ to $90^{\circ} \mathrm{C}$ at atmospheric pressure and 35\%o salinity, Chem. Geol., 97, 113-123, 1992.

Marion, G. M.: Carbonate mineral solubility at low temperatures in the Na-K-Mg-Ca-H-Cl-SO $-\mathrm{OH}-\mathrm{HCO}_{3}-\mathrm{CO}_{3}-\mathrm{CO}_{2}-\mathrm{H}_{2} \mathrm{O}$ system, Geochim. Cosmochim. Acta, 65, 1883-1896, 2001.

Marion, G. M.: A molal-based model for strong acid chemistry at low temperatures ( $<200$ to $298 \mathrm{~K}$ ), Geochim. Cosmochim. Acta, 66, 2499-2516, 2002.

Marion, G. M., Catling, D. C., and Kargel, J. S.: Modeling aqueous ferrous iron chemistry at low temperatures with application to Mars, Geochim. Cosmochim. Acta, 67, 4251-4266, 2003.

Marion, G. M., Catling, D. C., and Kargel, J. S.: Modeling gas hydrate equilibria in electrolyte solutions, CALPHAD, 30, 248259, 2006.

Marion, G. M., Catling, D. C., and Kargel, J. S.: Br/Cl partitioning in chloride minerals in the Burns formation on Mars, Icarus, 200, 436-445, 2009a.

Marion, G. M., Crowley, J. K., Thomson, B. J., Kargel, J. S., Bridges, N. T., Hook, S. J., Baldridge, A., Brown, A. J., Ribeiro da Luz, B., and de Souza Filho, C. R.: Modeling aluminumsilicon chemistries and application to Australian acidic playa lakes as analogues for Mars, Geochim. Cosmochim. Acta, 73, 3493-3511, 2009b.

Marion, G. M. and Farren, R. E.: Mineral solubilities in the Na$\mathrm{K}-\mathrm{Mg}-\mathrm{Ca}-\mathrm{Cl}-\mathrm{SO}_{4}-\mathrm{H}_{2} \mathrm{O}$ system: A re-evaluation of the sulfate chemistry in the Spencer-Møller-Weare model, Geochim. Cosmochim. Acta, 63, 1305-1318, 1999.

Marion, G. M. and Kargel, J. S.: Cold Aqueous Planetary Geochemistry with FREZCHEM: From Modeling to the Search for Life at the Limits, Springer, Heidelberg, Germany, 2008.

Marion, G. M., Kargel, J. S., and Catling, D. C.: Modeling ferrousferric iron chemistry with application to Martian surface geochemistry, Geochim. Cosmochim. Acta, 72, 242-266, 2008.

Marion, G. M., Kargel, J. S., Catling, D. C., and Jakubowski, S. D.: Effects of pressure on aqueous chemical equilibria at subzero temperatures with applications to Europa, Geochim. Cosmochim. Acta, 69, 259-274, 2005.

McCaffrey, M. A., Lazar, B., and Holland, H. D.: The evaporation path of seawater and the coprecipitation of $\mathrm{Br}^{-}$and $\mathrm{K}^{+}$with halite, J. Sed. Petrology, 57, 928-937, 1987. 
Millero, F. J.: Physical Chemistry of Natural Waters, WileyInterscience, New York, 2001.

Millero, F. J.: The marine inorganic carbon cycle, Chem. Rev., 107, 308-341, 2007.

Millero, F. J., Feistel, R., Wright, D. G., and McDougall, T. J.: The composition of Standard Seawater and the definition of the Reference-Composition Salinity Scale, Deep-Sea Res., 55, 5072, 2008.

Millero, F. J. and Kremling, K.: The densities of Baltic waters, Deep-Sea Res., 23, 1129-1138, 1976.

Millero, F. J. and Sohn, M. L.: Chemical Oceanography, CRC Press, Boca Raton, 1992.

Morse, J. W., Arvidson, R. S., and Lüttge, A.: Calcium carbonate formation and dissolution, Chem. Rev., 107, 342-381, 2007.

Morse, J. W. and He, S.: Influences of $T, S$ and $P_{\mathrm{CO}_{2}}$ on the pseudo-homogeneous precipitation of $\mathrm{CaCO}_{3}$ from seawater: implications for whiting formation, Mar. Chem., 41, 291-297, 1993.

Morse, J. W. and Mackenzie, F. T.: Geochemistry of Sedimentary Carbonates, Elsevier, Amsterdam, 1990.

Morse, J. W., Wang, Q., and Tsio, M. Y.: Influences of temperature and $\mathrm{Mg}: \mathrm{Ca}$ ratio on $\mathrm{CaCO}_{3}$ precipitates from seawater, Geol., 25, 85-87, 1997.

Omelon, C. R., Pollard, W. H., and Marion, G. M.: Seasonal formation of ikaite $\left(\mathrm{CaCO}_{3} 6 \mathrm{H}_{2} \mathrm{O}\right)$ in saline spring discharge at Expedition Fiord, Canadian High Arctic: Assessing conditional constraints for natural crystal growth, Geochim. Cosmochim. Acta, 65, 1429-1437, 2001.
Pauly, H.: "Ikaite", a new mineral from Greenland, Arctic, 16, 263264, 1963.

Pitzer, K. S.: Ion interaction approach: Theory and data correlation, in: Activity Coefficients in Electrolyte Solutions, 2nd Ed., CRC Press, Boca Raton, 75-153, 1991.

Pitzer, K. S.: Thermodynamics, 3rd Ed., McGraw-Hill, New York, 1995.

Pytkowicz, R. M.: Calcium carbonate retention in supersaturated seawater, Am. J. Sci., 273, 515-522, 1973.

Richardson, C.: Phase relationships in sea ice as a function of temperature, J. Glaciol., 17, 507-519, 1976.

Ringer, W. E.: Über die veränderungen in der Zusammensetzung des Meereswasseralzes beim Ausfrieren, Verh. Rijksinst. Onderz. Zee, 3, 1-55, 1906.

Rohde, K.-H.: Untersuchungen über die Calcium- und Magnesiumanomalie in der Ostsee, Beitr. Meeresk., 19, 18-31, 1966.

Steel, R. G. D., Torrie, J. H., and Dickey, D. A.: Principles and Procedures of Statististics: A Biometrical Approach, 3rd Ed., McGraw-Hill, Boston, 1997.

Weeks, W. F. and Ackley, S. F.: The growth, structure, and properties of sea ice, CRREL Monograph 82-1, USACRREL, Hanover, New Hampshire, 1982.

Zuddas, P. and Mucci, A.: Kinetics of calcite precipitation from seawater: II. The influence of the ionic strength, Geochim. Cosmochim. Acta, 62, 757-766, 1998. 